\title{
Hepatic fuel selection
}

\author{
BY MANFRED J. MÜLLER* \\ Max von Pettenkofer-Institut, Abteilung Ernährungsmedizin, Postfach 330013, D 14191 Berlin, \\ Germany
}

\section{Sélection des substrats énergétiques du foie}

\begin{abstract}
RÉSUMÉ
Le foie sert d'intermédiaire entre les sources d'énergie alimentaires et extra-hépatiques et les organes extra-hépatiques qui consomment de l'énergie. En pratique, quelque vingt-cinq composés sont soit absorbés, soit fournis en quantités substantielles par le foie. Les glucides, les acides gras libres, l'acétate, les acides aminés et l'éthanol sont des substrats producteurs d'énergie. Le foie utilise de l'énergie pour le transport et les fonctions sécrétoires, la synthèse et le stockage des macromolécules et des substrats énergétiques, les interconversions et le cyclage des substrats. In vivo, on peut estimer approximativement la consommation $\mathrm{d}^{\prime} \mathrm{O}_{2}$ par le foie en mesurant les différences de concentration artério- et porto-hépato-veineuse conjointement avec le flux sanguin dans l'artère hépatique et la veine porte. Chez l'adulte, le foie ne représente que $1 \cdot 5-2 \%$ du poids du corps, mais en même temps assume $20-25 \%$ de la dépense d'énergie au repos, ce qui suggère un taux élevé de métabolisme organique (environ $840 \mathrm{~kJ} / \mathrm{kg}$ de poids organique par jour). 'Etant donné la complexité de l'échange métabolique qui s'opère dans le foie, il est virtuellement impossible de déduire la valeur du mélange énergétique oxydé. Bien que différents flux métaboliques soient bien décrits dans nos ouvrages de référence, le métabolisme hépatique in vivo n'a pas été déterminé avec précision. Certains auteurs ont évalué directement. In vivo le quotient respiratoire $(Q R)$ dans la veine hépatique, citant des valeurs inférieures à $0 \cdot 70$, ce qui suggère une oxydation des graisses et une gluconéogenèse concomitantes dans les conditions basales. Cependant, l'interprétation du 'QR hépatique' est compliquée par des problèmes méthodologiques, par l'interconversion et l'oxydation incomplète des substrats, par le piégeage du $\mathrm{CO}_{2}$, par une inconnue sur l'oxydation des protéines hépatiques, par la consommation extramitochondriale et par l'hétérogénéité des tissus. On peut aussi mesurer indirectement le 'QR hépatique' en mesurant la consommation d' $\mathrm{O}_{2}$ hépatique conjointement avec l'échange des métabolites. Cette approche donne une limite supérieure de la contribution de l'oxydation de substrats à la consommation $\mathrm{d}^{\prime} \mathrm{O}_{2}$ et à la production de $\mathrm{CO}_{2}$. L'interprétation des données est rendue difficile par des problèmes méthodologiques, des affirmations erronées, le manque de substrats et la mesure de l'oxydation des acides aminés. Dans le jeûne, le 'QR hépatique' estimé varie entre 0.68 et $0 \cdot 71$. Après un repas varié, cette valeur s'élève entre 0.84 et 0.90 , ce qui suggére une oxydation concomitante d'acides aminés et de glucides. Si l'on suppose que tout le

* Present address: Institut für Humanernährung und Lebensmittelkunde, Christian-Albrechts-Universität zu Kiel, Düsternbrooker Weg 17, D24105 Kiel, Germany.
\end{abstract}


glucose est converti en graisse (ce qui est peu vraisemblable dans la réponse à un repas après le jeûne de la nuit), le 'QR hépatique' peut atteindre $2 \cdot 1$ au maximum. En ce qui concerne les nutriments individuels, ce sont les acides aminés qui exercent l'effet thermique le plus important, alors que les glucides n'augmentent pas la proportion splanchnique de l'augmentation de la consommation d' $\mathrm{O}_{2}$ du corps tout entier. Ces données suggèrent qu'après un repas la plus grande partie sinon la totalité des glucides est stockée, et l'oxydation hépatique du glucose exogène est négligeable. L'intégrité cellulaire, la disponibilité d'O $\mathrm{O}_{2}$ et de substrats, le flux sanguin hépatique total aussi bien que la proportion de flux sanguin artériel et portal, différentes hormones, le système nerveux autonome et un certain nombre de cytokines, tous ces éléments déterminent la sélection des substrats. Les substrats en provenance du foie à leur tour donnent aux autres tissus le signal d'activer ou d'inhiber les voies d'utilisation ou de production de tel ou tel substrat, affectant à nouveau la fonction métabolique du foie. Ainsi, le foie et les organes extra-hépatiques sont en étroite interaction dans la régulation du métabolisme de tout le corps, en réponse à des facteurs nutritionnels et autres.

\section{ENERGY-PROVIDING AND ENERGY-CONSUMING REACTIONS IN THE LIVER}

The liver serves as an intermediary between dietary and endogenous sources of energy and the extrahepatic organs that consume energy. Metabolically the liver is the most versatile organ of the body; about twenty-five compounds are either taken up or released in substantial amounts by the liver. Most of the present knowledge of hepatic fuel metabolism is based on in vitro experiments using the isolated perfused rat liver or rat hepatocytes. Normally the liver operates under highly aerobic conditions. Values for hepatic $\mathrm{O}_{2}$ consumption vary between 2 and $10 \mu \mathrm{mol} / \mathrm{g}$ liver wet weight per min (Berry et al. 1973; Krebs et al. 1974; Scholz et al. 1984; Rabkin \& Blum, 1985; Seifter \& Englard, 1988). Based on a P:O ratio of 3 (i.e. maximally efficient oxidative phosphorylation) the aerobic ATP supply could be calculated to vary between 12 and $60 \mu \mathrm{mol} / \mathrm{g}$ liver wet weight per min (Krebs et al. 1974). Most of the $\mathrm{O}_{2}$ consumed by the liver is related to mitochondrial metabolism. An additional $0.6-4.5 \mu \mathrm{mol}$ ATP/g liver wet weight per min may come from anaerobic metabolism of glucose (Krebs et al. 1974). Free fatty acids (FFA), pyruvate and amino acids are the preferred fuels of hepatic energy metabolism. Under basal aerobic conditions the liver primarily selects fatty acids as its fuel. If the liver selectively uses fatty acids its theoretical respiratory exchange ratio (RQ) would be 0.71 . Ureagenesis, futile cycling of substrates, gluconeogenesis, protein synthesis, $\mathrm{Na}^{+}, \mathrm{K}^{+}$-ATPase $(E C 3.6 .1 .37)$ and ketogenesis are the main energy-requiring processes in liver metabolism, and their maximum contributions to hepatic $\mathrm{O}_{2}$ consumption are 35, 22, 19, 11, 6 and 4\% respectively (Krebs et al. 1974; Jarett et al. 1979; Clark et al. 1982; Rabkin \& Blum, 1985). In the fed state, liver fuel mix changes and amino acids and pyruvate predominate as fuel, whereas most of the carbohydrate is stored as glycogen. At present, the exact contribution of other energy-consuming processes (e.g. hepatic protein degradation or bile acid secretion) to energy expenditure is unknown. In vitro, hepatic energy metabolism can be measured under controlled and highly standardized conditions. Cellular integrity and cellular function are well maintained throughout the studies, suggesting near physiological conditions. The drawback of the in vitro approach is that the data strongly depend on the experimental conditions (which are 
artificial) and, thus, may not reflect the physiological situation (Davis, 1961; Schwenke et al. 1981). In vitro studies provide a description of metabolic pathways and their individual capacities, but they cannot provide an integrated view of the physiology and pathophysiology of hepatic metabolism. Obviously, there is a need for in vivo assessment of hepatic fuel metabolism.

\section{IN VIVO ASSESSMENT OF HEPATIC FUEL SELECTION}

When compared with the abundance of in vitro data there is a lack of information on the metabolic rate of the liver in vivo. This lack of interest might be explained by the 'approximate' nature of the in vivo approach, which cannot give insights into the mechanisms and sites of metabolic regulation. In the intact organism, hepatic $\mathrm{O}_{2}$ consumption can be estimated, after catheterization, from the arterio- and portohepatovenous concentration differences and blood flow in the arteria hepatica and the portal vein. In an adult, the liver represents only $15-20 \mathrm{~g} / \mathrm{kg}$ body weight but accounts for $20-25 \%$ of the resting energy expenditure, suggesting a high organ metabolic rate (i.e. about $840 \mathrm{~kJ} / \mathrm{kg}$ organ weight per d when compared with 54 and $19 \mathrm{~kJ} / \mathrm{kg}$ organ weight per $\mathrm{d}$ in skeletal muscle and subcutaneous adipose tissue respectively; Elia, 1992). Given the complexity of the metabolic exchange occurring in the liver, it is virtually impossible to deduce the oxidized fuel mix in vivo. The $\mathrm{RQ}$ in the hepatic vein and, thus, the 'splanchnic RQ', which reflects liver plus gut metabolism, has been directly assessed in man (Tygstrup et al. 1965; Owen et al. 1969; Havel et al. 1970; Gil et al. 1985). In man, 'splanchnic $\mathrm{RQ}^{\prime}\left(\mathrm{RQ}_{\mathrm{m}}\right)$ of 0.37 (5-6 weeks of starvation, Owen et al. 1969) or 0.18 (overnight fasting, Havel et al. 1970) have been measured, suggesting increases in fat oxidation, ketogenesis and gluconeogenesis during overnight or prolonged starvation. Correcting the $\mathrm{RQ}\left(\mathrm{RQ}_{\mathrm{c}}\right)$ for (1) $V_{\mathrm{O}_{2}}$ due to ketogenesis and (2) fixation of $\mathrm{CO}_{2}$ during urea production, the splanchnic $\mathrm{RQ}_{\mathrm{c}}$ became 0.77 and 0.65 respectively. The interpretation of the 'splanchnic RQ' is made difficult by methodological problems (e.g. the measurement of $\mathrm{CO}_{2}$ content has a $\mathrm{CV}$ of $65 \%$ in the study of Gil et al. 1985), interconversion and incomplete oxidation of substrates, trapping of $\mathrm{CO}_{2}$ in the tissue bicarbonate pool, or an unknown rate of hepatic protein oxidation during ureagenesis, extramitochondrial $\mathrm{O}_{2}$ consumption and/or tissue heterogeneity (Frayn et al. 1993). Because of these problems the meaning of the 'splanchnic $R Q_{m}$ ' remains obscure. The 'hepatic RQ' or 'splanchnic RQ' can also be assessed indirectly from hepatic $\mathrm{O}_{2}$ consumption and exchange of metabolites, using the stoichiometry of substrate oxidation (Flatt, 1978, 1992; Frayn, 1983). Measurement of the arterio-venous concentration difference across the liver (or the splanchnic bed) shows whether the tissue(s) takes up or releases metabolites (Elia, 1991). This approach may give an upper limit to the contribution of substrate oxidation to $\mathrm{O}_{2}$ consumption and $\mathrm{CO}_{2}$ production. However, if the liver takes up substrates from the circulation, as well as releasing them, the net balance underestimates true uptake. The interpretation of data is made difficult by a number of methodological problems. The arterio-hepatovenous substrate difference is most frequently used instead of the arterial-portal venous-hepatovenous concentration differences (i.e. the 'splanchnic RQ' instead of the 'hepatic RQ'). In addition, the measurement of hepatic blood flow by dye-clearance techniques is not very accurate (i.e. variation of $30 \%$ ). In addition to the methodological problems, erroneous assumptions (e.g. all substrates come from outside the cell), missing fuel (e.g. an unknown rate of 
intrahepatic glycogen and fat mobilization) and the unknown rate of hepatic amino acid oxidation all limit the value of the indirect assessment of hepatic fuel mix.

\section{HEPATIC FUEL SELECTION IN STARVATION}

In starvation, the 'splanchnic RQ' has been directly assessed in subjects fasted for 5-6 weeks and was found to be $0 \cdot 37$, compatible with low $\mathrm{CO}_{2}$ production in relation to $\mathrm{O}_{2}$ consumption (Owen et al. 1969). These findings suggest increased rates of hepatic gluconeogenesis, fatty acid oxidation and ketogenesis during prolonged starvation. Most studies on hepatic metabolism in fasting man consider splanchnic instead of hepatic balances (Owen et al. 1969; Havel, 1974a; Dietze et al. 1978; Elia, 1991). During short-term starvation (i.e. up to $72 \mathrm{~h}$ ) hepatic fuel selection was measured in conscious and chronically catheterized miniature pigs (Müller et al. 1982, 1983; Table 1). In this study the aorta, the vena hepatica and the portal vein were catheterized. In the pig, fasting for $72 \mathrm{~h}$ increased hepatic $\mathrm{O}_{2}$ consumption and glucose output; concomitantly, the rates of urea and ketone-body production as well as amino acid and FFA uptake were all enhanced (Table 1). From the measurement of hepatic exchange of $\mathrm{O}_{2}$ and metabolites the starvation-induced 'hepatic RQ' was calculated to be 0.68 or 0.71 depending on the assumed unexplained fuel (Table 1). Thus, during tissue catabolism 'liver RQ' is lower than whole-body RQ. In the pig ketogenesis explained up to $28 \%$ of hepatic fatty acid metabolism or $22 \%$ of hepatic $\mathrm{O}_{2}$ consumption (Table 1). These values differ from those for humans and rats where hepatic ketone-body production accounts for $37 \%$ (after $69 \mathrm{~h}$ of starvation in man; Havel, 1974a), 72\% (after $120 \mathrm{~h}$ of starvation in man; Dietze et al. 1978) or $68 \%$ (after 24 h of starvation in the rat; Remesy \& Demigne, 1983 ) of splanchnic or hepatic FFA uptake. In man, the liver has a high capacity for producing ketone bodies (an estimate of $130-900 \mathrm{~g} / \mathrm{d}$ has been reported, Reichard et al. 1974; McGarry \& Foster, 1980) and ketogenesis accounted for up to $50 \%$ of hepatic $\mathrm{O}_{2}$ consumption (Havel, 1974b). In the pig, the major enzyme of ketone-body utilization (succinyl-CoA:3-ketoacid-transferase; $E C$ 2.8.3.5) could not be detected in the brain, thus, brain glucose consumption could not be replaced by ketone-body utilization (cf. Müller et al. 1982). Teleologically, this finding may explain the reduced ketone-body turnover that accompanies increased glucose turnover in pigs. Recalculating the pig data (Table 1) based on the assumption that $60 \%$ of hepatic FFA uptake was incompletely oxidized to ketone bodies led to an apparent 'hepatic RQ' of 0.20 after $72 \mathrm{~h}$ of starvation. It is evident that during starvation the 'hepatic RQ' does not only depend on fuel supply but results from the rate of hepatic ketogenesis. Since hepatic ketogenesis is not explained only by FFA supply (Keller et al. 1988), both substrate supply and the humoral milieu determine hepatic RQ during starvation.

To summarize, during short-term starvation the 'hepatic RQ', estimated from hepatic $\mathrm{O}_{2}$ consumption and metabolite exchange, varies between 0.20 and 0.71 depending on the rate of ketogenesis. In this situation the 'hepatic RQ' is lower than whole-body RQ.

\section{HEPATIC FUEL SELECTION IN THE POSTPRANDIAL STATE}

After a mixed meal, splanchnic $\mathrm{O}_{2}$ consumption increased (Brundin et al. 1992; Brundin, 1993). The splanchnic-related proportion of the rise in whole-body $\mathrm{O}_{2}$ consumption in the $2 \mathrm{~h}$ after a mixed meal, a carbohydrate meal containing fructose or glucose, a protein 
Table 1. Hepatic substrate metabolism and energy balance during metabolic adaptation to starvation as measured in the conscious unrestrained miniature pig (From Müller et al. 1982, 1983)

(Mean values and standard deviations for four to seven pigs; body wt $21 \mathrm{~kg}$; liver wt:body wt $24 \mathrm{~g} / \mathrm{kg}$ )

\begin{tabular}{|c|c|c|c|c|c|c|}
\hline \multirow[t]{2}{*}{ Starvation period $(\mathrm{h}) \ldots$} & \multicolumn{2}{|c|}{0} & \multicolumn{2}{|c|}{24} & \multicolumn{2}{|c|}{72} \\
\hline & Mean & SD & Mean & SD & Mean & SD \\
\hline Blood flow ( $\mathrm{ml} / \mathrm{kg}$ body wt per $\mathrm{min}$ ) & $38 \cdot 2$ & $2 \cdot 3$ & $42 \cdot 6$ & $6 \cdot 5$ & $43 \cdot 6$ & $5 \cdot 9$ \\
\hline $\mathrm{O}_{2}$ consumption $(\mu \mathrm{mol} / \mathrm{kg}$ body wt per $\mathrm{min})$ & $\cdot 41 \cdot 6$ & $3 \cdot 6$ & $56 \cdot 1$ & $3 \cdot 8$ & $53 \cdot 3$ & $6 \cdot 6$ \\
\hline \multicolumn{7}{|l|}{$\begin{array}{l}\text { Substrate and energy balance ( } \mu \mathrm{mol} / \mathrm{kg} \\
\text { body wt per min) }\end{array}$} \\
\hline Glucose & $+9 \cdot 1$ & $3 \cdot 0$ & $+24 \cdot 0$ & $6 \cdot 7$ & $+20 \cdot 5$ & $3 \cdot 4$ \\
\hline Alanine $\rightarrow$ glucose* & \multicolumn{2}{|c|}{0} & $+14 \cdot 7$ & $2 \cdot 3$ & $8 \cdot 5$ & $2 \cdot 1$ \\
\hline $\mathrm{CO}_{2}$ used for urea production & & & \multicolumn{2}{|c|}{$-7 \cdot 4$} & \multicolumn{2}{|c|}{$-4 \cdot 3$} \\
\hline$V_{\mathrm{O}_{2}}$ correction for pyruvate production & \multicolumn{2}{|c|}{$0 \cdot 2$} & \multicolumn{2}{|c|}{0} & \multicolumn{2}{|c|}{0} \\
\hline Lactate & $-5 \cdot 9$ & $3 \cdot 6$ & $-10 \cdot 0$ & $3 \cdot 1$ & -6.5 & 0.8 \\
\hline Lactate $\rightarrow \mathrm{CO}^{\dagger}$ & \multicolumn{2}{|c|}{$3 \cdot 0$} & \multicolumn{2}{|c|}{$2 \cdot 0$} & \multicolumn{2}{|c|}{0.7} \\
\hline$V_{\mathrm{O}_{2}}$ & \multicolumn{2}{|c|}{$9 \cdot 0$} & \multicolumn{2}{|c|}{$6 \cdot 0$} & \multicolumn{2}{|c|}{$2 \cdot 1$} \\
\hline$V_{\mathrm{CO}} \ddagger$ & \multicolumn{2}{|c|}{$6 \cdot 0$} & \multicolumn{2}{|c|}{$4 \cdot 0$} & \multicolumn{2}{|c|}{$1 \cdot 4$} \\
\hline Free fatty acids & $+0 \cdot 1$ & $0 \cdot 0$ & $-2 \cdot 1$ & $0 \cdot 8$ & $-6 \cdot 3$ & $2 \cdot 1$ \\
\hline Ketone bodies & $+0 \cdot 3$ & $0 \cdot 1$ & $+4 \cdot 2$ & $1 \cdot 7$ & $+7 \cdot 2$ & $3 \cdot 2$ \\
\hline$\beta$ HOB:AcAc $\$$ & \multicolumn{2}{|c|}{1.90} & \multicolumn{2}{|c|}{1.25} & \multicolumn{2}{|c|}{1.58} \\
\hline Free fatty acids $\rightarrow:$ Ketone bodies $\|$ & \multicolumn{2}{|c|}{0} & \multicolumn{2}{|c|}{$1 \cdot 1$} & \multicolumn{2}{|c|}{$1 \cdot 8$} \\
\hline $\mathrm{CO}_{2} 9$ & \multicolumn{2}{|c|}{0} & \multicolumn{2}{|c|}{$1 \cdot 0$} & & \\
\hline$V_{\mathrm{O}_{2}}$ & ( & & 23 & & 16 & \\
\hline$V_{\mathrm{CO}_{2}}$ & c & & 16 & & 11 & \\
\hline$V_{\mathrm{O}_{2}}$ due to: AcAc produced** & $\mathrm{c}$ & & 4 & & 10 & \\
\hline$\beta H O B$ produced** & ( & & 2 & & & \\
\hline Amino acids $+\dagger$ & $-49 \cdot 6$ & $14 \cdot 2$ & -18.4 & $5 \cdot 8$ & $-11 \cdot 3$ & $3 \cdot 7$ \\
\hline Urea & $+2 \cdot 3$ & $2 \cdot 9$ & $+4 \cdot 5$ & $0 \cdot 6$ & $+5 \cdot 2$ & $1 \cdot 3$ \\
\hline Amino acids $\rightarrow:$ Urea & 4 & & 9 & & 10 & \\
\hline $\mathrm{CO}_{2}+\mathrm{f}^{2}$ & 3 & & 2 & & & \\
\hline$V_{\mathrm{O}_{2}}$ & 16 & & 13 & & 15 & \\
\hline$V_{\mathrm{CO}_{2}}$ & 13 & & 11 & & 12 & \\
\hline $\mathrm{CO}_{2}$ used for urea production & 2 & & 4 & & & \\
\hline Unexplained fuel§\&\|!| & 16 & & 6 & & & \\
\hline Fuel mix $(\%)$ & & & & & & \\
\hline Carbohydrates & $62 \$ \$$ & & $22 \$ \$$ & & $17 \S \S$ & \\
\hline Lipids & $0 \$$ & & $54 \$ 8$ & & 5388 & \\
\hline Amino acids & $39 \$ \S$ & & $25 \S \S$ & & $30 \S \S$ & \\
\hline Apparent 'tissue' $\mathrm{RQ}$ & $0.90 \$ \S$ & 84||$\|$ & $0.75 \$ \$$ & $73|\||$ & $0.71 \S \S$ & $68|\||$ \\
\hline
\end{tabular}

$\beta$ HOB, $\beta$-hydroxybutyrate; AcAc, acetoacetate.

* Assuming a maximum conversion efficiency, i.e. all alanine is converted to glucose.

$\dagger$ Assuming that $50(0 \mathrm{~h})$ or $20 \%(24$ and $72 \mathrm{~h})$ of the extracted lactate is oxidized.

After correction for possible $\mathrm{CO}_{2}$ retention in the tissue bicarbonate pool because of $\mathrm{H}^{+}$production.

$\S$ As calculated from the hepatovenous substrate concentrations.

$\|$ As calculated from hepatic free fatty acid extraction and ketone-body production assuming a fatty acid chain length of $\mathrm{C}_{18}$.

If As calculated from the difference between hepatic oxygen consumption minus $V_{\mathrm{O}}$ due to carbohydrate and amino acid oxidation plus incomplete oxidation of free fatty acids to ketone bodies.

** Assuming 1.75 mol $\mathrm{O}_{2}$ consumed/mol AcAc produced and $1.25 \mathrm{~mol} \mathrm{O} \mathrm{O}_{2}$ consumed $/ \mathrm{mol} \beta \mathrm{HOB}$ produced. The calculation is based on the hepatic production rate of the individual ketone bodies.

$+\dagger$ As calculated from the net balance of $\alpha$-amino- $\mathrm{N}$.

As calculated from the urea production rate assuming that $70(0 \mathrm{~h})$ or $30 \%(24$ and $72 \mathrm{~h})$ of the amino acid-C skeleton is directly oxidized.

$\S \S$ Unexplained fuel is explained as glucose oxidation.

||| Unexplained fuel is explained as $50 \%$ glucose and $50 \%$ lipid oxidation derived from hepatic energy stores $(0 \mathrm{~h})$, or $30 \%: 70 \%(24 \mathrm{~h})$ and $15 \%: 85 \%(72 \mathrm{~h})$ respectively. 


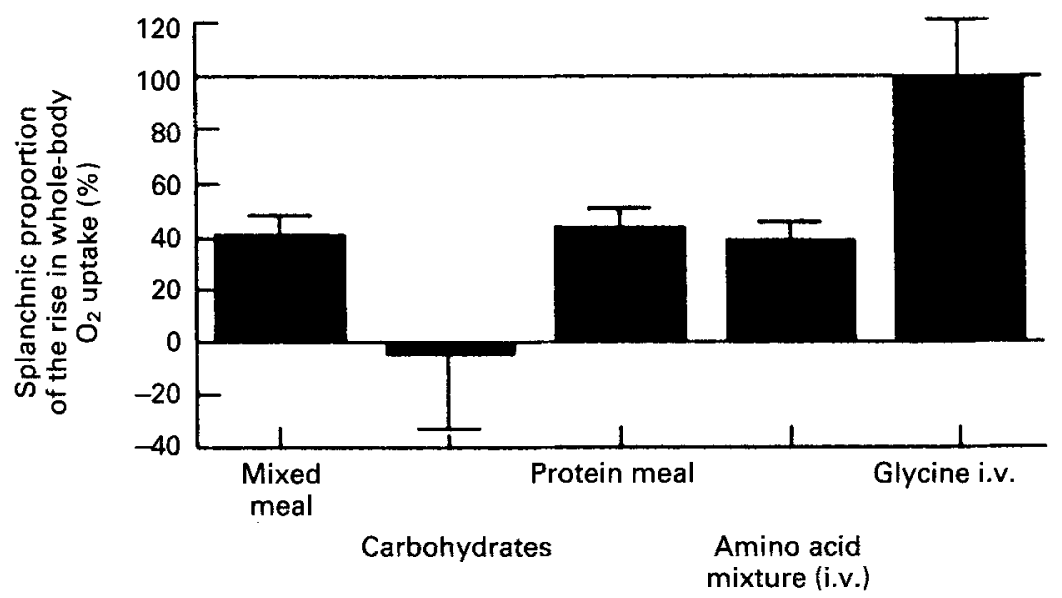

Fig. 1. Splanchnic proportion of the rise in whole-body $\mathrm{O}_{2}$ consumption in the $2 \mathrm{~h}$ after a mixed meal containing $40 \%$ of basal energy requirements. Carbohydrate meals contained $75 \mathrm{~g}$ fructose or glucose. The protein meal contained $900 \mathrm{~kJ}$ fish meat. Amino acids were infused at a rate of $240 \mathrm{~kJ} / \mathrm{h}$. A mixture of nineteen amino acids or glycine alone was infused intravenously (i.v.). Experiments were performed on thirty-four healthy normal weight men. Values are means with their standard errors represented by vertical bars. (Data from Brundin (1993); reproduced with kind permission of Professor John Wahren.)

meal or after intravenous infusion of amino acids is shown in Fig. 1 (Brundin \& Wahren, $1993,1994)$. The findings suggest that the postprandial rise in splanchnic $\mathrm{O}_{2}$ consumption was substrate specific. Amino acids had a strong thermic effect on hepatic metabolism, whereas exogenous carbohydrates were mostly stored postprandially. The latter idea is supported by several lines of evidence. First, the postprandial hepatic glycogen synthesis accounts for $20-30 \%$ of an oral glucose load (i.e. 15-30 g; Kelley et al. 1988; Radziuk, 1989). In humans, hepatic glycogen content is about $70-100 \mathrm{~g}$ (i.e. about $7-10 \%$ of liver wet weight) with a turnover of about $47 \mathrm{~g} / \mathrm{d}$ (Rothman et al. 1991; Gay et al. 1994). This value is in line with the minimal estimate of the proportion of oral glucose taken up by the splanchnic bed (i.e. 25-30\%; Jackson et al. 1983; Ferrannini et al. 1985; Kelley et al. 1988). Second, at the whole-body level $30-40 \%$ of the oral glucose was oxidized directly in brain, heart and skeletal muscle (Ebiner et al. 1979; Kelley et al. 1988), leaving only $1-2 \%$ of the oral glucose for oxidation in splanchnic and other tissues. This is in line with the finding that up to $4 \%$ of an oral glucose load is oxidized within the splanchnic area (Abumrad et al. 1982). Third, since hepatic glycogen synthesis and degradation are active simultaneously in fed and fasted rats and humans (David et al. 1990; Magnusson et al. 1994), glucose oxidation may occur after mobilization of glycogen. In man, minimum estimates of the relative liver glycogen turnover were $31 \%$ in the fasted state and $57 \%$ in the fed state (Magnusson et al. 1994). In the fed state the flux through glycogen synthase (EC 2.4.1.11) was $0.53 \mu \mathrm{mol} / \mathrm{ml}$ liver per min and glycogen breakdown was calculated to be $0.30 \mu \mathrm{mol} / \mathrm{ml}$ liver per min (Magnusson et al. 1994). After a glucose load hepatic glucose output decreased from 11.1 to $4.4 \mu \mathrm{mol} / \mathrm{kg}$ body weight per min (Kelley et al. 1988). Assuming that hepatic glycogen breakdown was unchanged in the fed state, hepatic glucose oxidation from endogenous sources could reach a maximum of 6.7 $\mu \mathrm{mol} / \mathrm{kg}$ body weight per min. This value is close to the estimated rate of hepatic 
glycogenolysis based on experiments using liver-biopsy techniques (i.e. $6.9 \mu \mathrm{mol} / \mathrm{kg}$ body weight per min or $0.32 \mu \mathrm{mol} / \mathrm{g}$ liver per min; Nilsson et al. 1973) and ${ }^{13} \mathrm{C}$ NMR studies. The importance of net hepatic lipogenesis is less evident in man. It is unlikely that quantitatively significant lipogenesis occurs when a carbohydrate load is preceded by overnight fasting (Hellerstein et al. 1991, 1993); in non-obese, non-diabetic and non-overfed healthy subjects only about $1 \mathrm{~g}$ fat was synthesized in response to a variety of feeding regimens (Hellerstein et al. 1991). Lipogenesis remains low in subjects overfed carbohydrates in a mixed diet (Thomas et al. 1992). Substantial lipogenesis occurs after hepatic glycogen stores are fully saturated by massive intakes of glucose (for example, $500 \mathrm{~g}$ glucose; Acheson et al. 1988).

The present evidence suggests that after a meal most, if not all, carbohydrate is stored as glycogen, and hepatic oxidation of exogenous glucose and hepatic lipogenesis are negligible. Postprandially, hepatic RQ increases to $0 \cdot 84-0 \cdot 90$, suggesting concomitant amino acid and carbohydrate oxidation (Table 1). Assuming that $50 \%$ of the missing fuel is explained by $\mathrm{O}_{2}$ consumption due to lipogenesis an RQ of 1.04 can be calculated. If all the glucose is converted to fat (which is unlikely in response to a meal after an overnight fast) hepatic $\mathrm{RQ}$ can reach $2 \cdot 1$. Of the individual nutrients amino acids exert the strongest thermic effect. During tissue anabolism 'splanchnic RQ' may equal or exceed 'whole-body RQ'.

\section{HEPATIC FUEL SELECTION DURING EXERCISE}

During exercise the liver provides substrates (1) to maintain fuel homeostasis (i.e. to maintain euglycaemia), (2) to meet muscle energy demands and (3) to conserve $C$ as well as $\mathrm{N}$ (Wasserman \& Cherrington, 1991). While muscle glycogen provides the first source of energy, liver fuel production becomes of increasing importance with increasing duration of exercise. Splanchnic blood flow decreases in response to heavy exercise (i.e. $55-60 \%$ of $V_{\mathrm{O}_{2} \max }$ for $40 \mathrm{~min}$; Wahren et al. 1975). Concomitantly, $\mathrm{O}_{2}$ and lactate uptake, gluconeogenesis, glycogenolysis and hepatic output of glucose all increase, whereas total amino acid balance across the splanchnic bed decreases. Splanchnic glucose output increases two- to fivefold, depending on the intensity of the work performed (Felig \& Wahren, 1975). In healthy subjects, the splanchnic balances of FFA and ketone bodies are unaltered or decreased in response to exercise (Hagenfeldt \& Wahren, 1973; Wahren et al. 1975). However, hepatic FFA uptake and ketogenesis increase with prolonged exercise (Wasserman \& Cherrington, 1991). Assuming an hepatic glycogen breakdown of $2.50 \mathrm{mmol} / \mathrm{min}$, which adds to plasma substrates as an energy fuel, an apparent splanchnic RQ of 0.88 was calculated during heavy exercise. During moderate and prolonged exercise $\left(30 \% V_{\mathrm{O}_{2} \max }, 4 \mathrm{~h}\right)$ splanchnic $\mathrm{O}_{2}$ consumption and the uptakes of lactate, FFA and amino acids all increase but glycogen stores decrease (Ahlborg et al. 1974; Wasserman \& Cherrington, 1991). This is associated with an increase in gluconeogenesis, splanchnic glucose output, fat oxidation and ketogenesis. Splanchnic glucose output increases twofold in $40 \mathrm{~min}$ and remains constant thereafter (Felig \& Wahren, 1975). In addition to hepatic FFA uptake, the mobilization of intrahepatic fat stores may also add to hepatic fat oxidation and ketogenesis. During prolonged exercise hepatic ketogenic efficiency may reach $40 \%$ of hepatic FFA uptake (Wasserman \& Cherrington, 1991). Assuming a ketone-body production of 0.22 $\mathrm{mmol} / \mathrm{min}$ (Wasserman \& Cherrington, 1991), after prolonged exercise a splanchnic RQ 
of 0.65 can be calculated. Thus, during prolonged exercise 'splanchnic $R Q$ ' is lower than 'whole-body RQ'.

\section{HEPATIC FUEL SELECTION IN LIVER CIRRHOSIS}

In cirrhosis, basal splanchnic $\mathrm{O}_{2}$ consumption was variable, but lower-than-normal mean values were found in groups of patients (Merli et al. 1986; Bahr, 1994; Müller et al. $1994 a, b)$. Postabsorptive splanchnic glucose output also was highly variable and mean values were low (Owen et al. 1981, 1985; Nosadini et al. 1984; Merli et al. 1986; Bahr, 1994; Müller et al. 1994b). Both reduced gluconeogenesis and reduced glycogen concentrations add to reduced hepatic glucose output in cirrhotic patients. Splanchnic uptake of FFA was normal or increased (Owen et al. 1981; Merli et al. 1986; Bahr, 1994). Reported values for cirrhotic patients range from lower to higher than normal (Owen et al. 1981; Nosadini et al. 1984; Merli et al. 1986; Müller et al. 1994b). The rate of ketone-body production in response to increased FFA supply was reduced suggesting impaired ketogenesis in cirrhosis (Müller et al. 1992). Urea production rate was highly variable in cirrhosis, but normal mean values were found in groups of patients (Owen et al. 1981; Merli et al. 1986; Bahr, 1994). The calculation of the 'splanchnic RQ', based on the data of Merli et al. (1986), led to a value of 0.55 in cirrhosis when compared with 0.69 in healthy controls. The low 'hepatic RQ' suggests tissue catabolism, and is in line with hepatic glucose oxidation limited by reduced glycogen stores (Owen et al. 1981, 1983). In cirrhosis, the 'hepatic RQ' is less than the low 'whole-body RQ' reflecting hepatic as well as whole-body tissue catabolism.

\section{DETERMINANTS OF HEPATIC FUEL SELECTION}

Liver fuel selection is tightly controlled by a number of different factors. The substrates coming from the liver are signals to other tissues (e.g. skeletal muscle) to activate or inhibit pathways of utilization or production of one fuel or another, thereby affecting the metabolic function of the liver. Thus, the liver and extrahepatic organs closely interact in the regulation of whole-body metabolism in response to nutritional and other factors (Elia, 1991). Cellular integrity, $\mathrm{O}_{2}$ and substrate supply, total hepatic blood flow as well as the proportion of arterial and portal blood flow, local mediators, hormones (insulin, glucagon, growth hormone, thyroid hormones, cortisol), the autonomic nervous system, metabolic factors (FFA, glucose) and a number of cytokines (tumour necrosis factor $\alpha$, interleukins 1 and 6 , transforming growth factor $\beta$, epidermal growth factor, insulin-like growth factor; Andus et al. 1991) all determine hepatic fuel selection. In some physiological situations, substrate supply is an important determinant of liver metabolism and may become rate-limiting. In starvation, the increased endogenous substrate (FFA) supply, metabolic factors (increase in plasma FFA at decreased glucose concentrations) and the alterations in the humoral milieu (fall in plasma insulin levels, a decreased activity of the sympathetic nervous system at concomitantly increased plasma glucagon concentrations) together explain hepatic fuel selection. In the postprandial state, increased splanchnic perfusion, the portal venous substrate concentration (e.g. hyperglycaemia in the portal blood; Adkins et al. 1987), the fall in the glucagon:insulin ratio and FFA levels in the portal blood all determine hepatic fuel metabolism. In the well-insulinized state hyperglycaemia inhibits hepatic glucose production and, thus, 
alters hepatic energy demands (Müller et al. 1988, 1990). In addition, the postprandial activation of the sympathetic nervous system favours hepatic energy flux and tissue anabolism. During exercise splanchnic circulation decreases but endogenous substrate supply increases. Concurrently, FFA, glucagon and the sympathetic nervous system stimulate liver metabolism in order to meet the energy demands of the extrahepatic tissues. During moderate exercise hepatic fuel metabolism was related primarily to the glucagon:insulin ratio rather than the fall in insulin secretion alone (Wasserman \& Cherrington, 1991; Vranic, 1992). Together the two hormones control almost $100 \%$ of hepatic glucose production (Wasserman \& Cherrington, 1991). During prolonged exercise FFA become more important both as a fuel and as determinants of increased gluconeogenesis: FFA delivery to the liver, FFA uptake and hepatic oxidation as well as ketogenesis are all increased. Increased FFA oxidation increased hepatic gluconeogenesis (Yamatani et al. 1992). During intense exercise catecholamines become major regulators. In cirrhosis, splanchnic circulation is more or less disturbed and there is a loss in cellular integrity and liver function. The present evidence suggests that the physiological factors regulating hepatic fuel metabolism become less important in the cirrhotic liver. In acute liver disease, prostaglandins and cytokines produced locally and/or systemically may exert profound effects on liver metabolism. Their exact contribution is presently unknown.

\section{CONCLUSION}

Although hepatic intermediary metabolism is well characterized by numerous in vitro studies there are only a few in vivo data on hepatic fuel selection. Since in vitro experiments may not reflect the physiological situation, there is a need for in vivo studies. In the liver, the direct and indirect assessments of metabolic functions are limited by certain methodological problems. As a consequence the present evidence is based on a number of assumptions which have to be proven in future studies. The liver is responsible for $20-30 \%$ of whole-body energy expenditure. Hepatic fuel selection can change considerably in different circumstances. During catabolism the 'hepatic RQ' is lower than the whole-body RQ. By contrast, the hepatic RQ may exceed whole-body $\mathrm{RQ}$ during extreme anabolism (i.e. after full repletion of hepatic glycogen stores and significant lipogenesis). Amino acids exert a strong thermic effect on liver metabolism, whereas exogenous carbohydrate is stored and does not meet directly hepatic energy demands. Several determinants integrate hepatic metabolism into whole-body metabolism. The individual determinants of hepatic fuel selection are of varying importance during different physiological and pathophysiological situations. Physiological determinants of hepatic metabolism become secondary in liver cirrhosis, where disturbances in splanchnic haemodynamics and the loss in cellular integrity are the predominant factors.

\section{REFERENCES}

Abumrad, N. N., Cherrington, A. D., Williams, P. E., Lacy, W. W. \& Rabin, D. (1982). Adsorption and disposition of a glucose load in the conscious dog. American Journal of Physiology 242, E398-E406.

Acheson, K., Schutz, Y., Bessard, T., Anantharaman, K., Flatt, J. P. \& Jequier, E. (1988). Glycogen storage capacity and de novo lipogenesis during massive carbohydrate overfeeding in man. American Journal of Clinical Nutrition 48, 240-247. 
Adkins, B. A., Myers, S. R., Hendrick, G. K., Stevenson, R. W., Williams, P. E. \& Cherrington, A. D. (1987). Importance of the rate of intravenous glucose delivery to hepatic glucose balance in the conscious dog. Journal of Clinical Investigation 79, 557-565.

Ahlborg, G., Felig, P., Hagenfeldt, L., Hendler, R. \& Wahren, J. (1974). Substrate turnover during prolonged exercise. Journal of Clinical Investigation 53, 1080-1090.

Andus, T., Bauer, J. \& Gerok, W. (1991). Effects of cytokines on the liver. Hepatology 13, 364-375.

Bahr, M. (1994). Energiestoffwechsel und hepatische Haemodynamik bei Patienten mit Leberzirrhose (Energy expenditure and splanchnic haemodynamics in patients with liver cirrhosis). Doctoral Thesis, Medizinische Hochschule Hannover, Hannover.

Berry, M. N., Kun, E. \& Werner, H. V. (1973). Regulatory role of reducing equivalent transfer from substrate to oxygen in the hepatic metabolism of glycerol and sorbitol. European Journal of Biochemistry 33, $407-417$.

Brundin, T. (1993). Mechanisms of nutrient-induced thermogenesis: total and splanchnic oxygen consumption and blood flow. International Journal of Obesity, Suppl. 3, S52-S55.

Brundin, T., Thörne, A. \& Wahren, J. (1992). Heat leakage across the abdominal wall and meal-induced thermogenesis in normal-weight and obese subjects. Metabolism 41, 49-55.

Brundin, T. \& Wahren, J. (1993). Whole body and splanchnic oxygen consumption and blood flow after oral ingestion of fructose or glucose. American Journal of Physiology 264, E504-E513.

Brundin, T. \& Wahren, J. (1994). Effects of i.v. amino acids on human splanchnic and whole body oxygen consumption, blood flow and blood temperatures. American Journal of Physiology 266, E396-E402.

Clark, D. G., Brinkman, M., Filsell, O. H., Lewis, S. J. \& Berry, M. N. (1982). No major role for $\left(\mathrm{Na}^{+} \mathrm{K}^{+}\right)$-dependent adenosine triphosphatase apparent in hepatocytes from hyperthyroid rats. Biochemical Journal 202, 661-665.

David, M., Petit, W. A., Laughlin, M. R., Shulman, R., King, J. E. \& Barrett, E. J. (1990). Simultaneous synthesis and degradation of rat liver glycogen. An in vitro nuclear magnetic resonance spectroscopic study. Journal of Clinical Investigation 86, 612-617.

Davies, M. (1961). On body size and tissue respiration. Journal of Cellular and Comparative Physiology 57, $135-147$.

Dietze, G., Wicklmayr, M. \& Mehnert, H. (1978). On the key role of ketogenesis for the regulation of glucose homoeostasis during fasting: Intrahepatic control, ketone levels and peripheral pyruvate oxidation. In Biochemical and Clinical Aspects of Ketone Body Metabolism, pp. 213-225 [H. D. Söling and C. D. Seufert, editors]. Stuttgart: G. Thieme Publisher.

Ebiner, I. R., Acheson, K. J., Doerner, A., Maeder, E., Arnaud, M. J., Jequier, E. \& Felber, J. P. (1979). Comparison of carbohydrate utilization in man using indirect calorimetry and mass spectrometry after an oral load of $100 \mathrm{~g}$ naturally labelled $\left[{ }^{13} \mathrm{C}\right]$ glucose. British Journal of Nutrition 41, 419-429.

Elia, M. (1991). The inter-organ flux of substrates in fed and fasted man, as indicated by arterio-venous balance studies. Nutrition Research Reviews 4, 3-31.

Elia, M. (1992). Organ and tissue contribution to metabolic rate. In Energy Metabolism: Tissue Determinants and Cellular Corollaries, pp. 61-80 [J. M. Kinney and H. N. Tucker, editors]. New York: Raven Press Ltd.

Felig, P. \& Wahren, J. (1975). Fuel homeostasis in exercise. New England Journal of Medicine 293, $1078-1084$.

Ferrannini, E., Bjorkman, O., Reichard, G., Pilo, A., Olsson, M., Wahren, J. \& DeFronzo, R. (1985). The disposal of an oral glucose load in healthy subjects: a quantitative study. Diabetes 34, 580-588.

Flatt, J. P. (1978). The biochemistry of energy expenditure. In Recent Advances in Obesity Research, vol. 2, pp. 211-218 [G. Bray, editor]. London: Newman Publishing.

Flatt, J. P. (1992). Energy costs for ATP synthesis. In Energy Metabolism: Tissue Determinants and Cellular Corollaries, pp. 319-342 [J. M. Kinney and H. N. Tucker, editors]. New York: Raven Press Ltd.

Frayn, K. N. (1983). Calculation of substrate oxidation rates in vivo from gaseous exchange. Journal of Applied Physiology 55, 628-634.

Frayn, K. N., Lund, P. \& Walker, M. (1993). Interpretation of oxygen and carbon dioxide exchange across tissue beds in vivo. Clinical Science $\mathbf{8 5}, 373-384$.

Gay, L. J., Schneiter, Ph., Schutz, Y., Di Vetta, V., Jequier, E. \& Tappy, L. (1994). A non-invasive assessment of hepatic glycogen kinetics and post-absorptive gluconeogenesis in man. Diabetologia 37, $517-523$

Gil, K. M., Gump, F. E., Starker, P. M., Askanazy, J., Elwyn, D. H. \& Kinney, J. M. (1985). Splanchnic substrate balance in malnourished patients during parenteral nutrition. American Journal of Physiology 248, E409-E419. 
Hagenfeldt, L. \& Wahren, J. (1973). Effect of exercise on splanchnic exchange of free fatty acids. Metabolism $22,815-820$.

Havel, R. J. (1974a). Interrelationship between carbohydrate and lipid metabolism in the splanchnic region in man. In Regulation of Hepatic Metabolism, pp. 180-190 [F. Lundquist and N. Tygstrup, editors]. Copenhagen: Munksgaard.

Havel, R. J. (1974b). Splanchnic and extrasplanchnic use of fuels in man. In Regulation of Hepatic Metabolism, pp. 612-616 [F. Lundquist and N. Tygstrup, editors]. Copenhagen: Munksgaard.

Havel, R. J., Kane, J. P., Balasse, E. O., Segel, N. \& Basso, L. V. (1970). Splanchnic metabolism of free fatty acids and production of triglycerides of very low density lipoproteins in normotriglyceridemic and hypertriglyceridemic humans. Journal of Clinical Investigation 49, 2017-2035.

Hellerstein, M. K., Christiansen, M., Kaempfer, S., Kletke, C., Wu, K., Reid, J. S., Hellerstein, S. \& Shackleton, C. H. L. (1991). Measurement of de novo hepatic lipogenesis in humans using stable isotopes. Journal of Clinical Investigation 87, 1841-1852.

Hellerstein, M. K., Neese, R. A. \& Schwarz, J.-M. (1993). Model for measuring absolute rates of hepatic de novo lipogenesis and reesterification of free fatty acids. American Journal of Physiology 265, E814-E820.

Jackson, R., Blix, P., Matthews, J., Morgan, L., Rubenstein, A. \& Nabarro, J. (1993). Comparison of peripheral glucose uptake after oral glucose loading and a mixed meal. Metabolism 32, 706-710.

Jarrett, I. G., Clark, D. G., Filsell, O. H., Harvey, J. W. \& Clark, M. G. (1979). The application of microcalorimetry to the assessment of metabolic efficiency in isolated rat hepatocytes. Biochemical Journal $180,631-638$.

Keller, U., Gerber, P. P. G. \& Stauffacher, W. (1988). Fatty acid-independent inhibition of hepatic ketone body production by insulin in humans. American Journal of Physiology 254, E694-E699.

Kelley, D., Mitrakou, A., Marsh, H., Schwenk, F., Benn, J., Sonnenberg, G., Arcangeli, M., Aoki, T., Sorensen, J., Berger, M., Sonksen, P. \& Gerich, J. (1988). Skeletal muscle glycolysis, oxidation and storage of an oral glucose load. Journal of Clinical Investigation 81, 1563-1571.

Krebs, H. A., Cornell, N. W., Lund, P. \& Hems, R. (1974). Some aspects of hepatic energy metabolism. In Regulation of Hepatic Metabolism, pp. 549-565 [F. Lundquist and N. Tygstrup, editors]. Copenhagen: Munksgaard.

McGarry, J. D. \& Foster, D. W. (1980). Regulation of free fatty acid oxidation and ketone body production. Annual Review of Biochemistry 49, 395-420.

Magnusson, I., Rothman, D. L., Jucker, B., Cline, G. W., Shulman, R. G. \& Shulman, G. I. (1994). Liver glycogen in fed and fasted humans. American Journal of Physiology 266, E796-E803.

Merli, M., Eriksson, L. S., Hagenfeldt, L. \& Wahren, J. (1986). Splanchnic and leg exchange of free fatty acids in patients with cirrhosis. Journal of Hepatology 3, 348-355.

Müller, M. J., Acheson, K. J., Burger, A. G. \& Jequier, E. (1990). Evidence that hyperglycemia per se does not inhibit hepatic glucose production in man. European Journal of Applied Physiology 60, $293-299$.

Müller, M. J., Böker, K. H. W. \& Selberg, O. (1994a). Are patients with liver cirrhosis hypermetabolic? Clinical Nutrition 13, 131-144.

Müller, M. J., Böker, K. H. W. \& Selberg, O. (1994b). Metabolism of energy yielding substrates in liver cirrhosis. Clinical Investigator (In the Press).

Müller, M. J., Möhring, J. \& Seitz, H. J. (1988). Regulation of hepatic glucose output by glucose in vivo. Metabolism 37, 55-60.

Müller, M. J., Paschen, U. \& Seitz, H. J. (1982). Starvation-induced ketone body production in the conscious unrestrained miniature pig. Journal of Nutrition 112, 1379-1386.

Müller, M. J., Paschen, U. \& Seitz, H. J. (1983). Glucose production measured by tracer and balance data in conscious miniature pig. American Journal of Physiology 244, E236-E244.

Müller, M. J., Rieger, A., Willmann, O., Lautz, H. U., Balks, H. J,, von zur Mühlen, A., Canzler, H. \& Schmidt, F. W. (1992). Metabolic responses to lipid infusions in patients with liver cirrhosis. Clinical Nutrition 11, 193-206.

Nilsson, L. H., Fürst, P. \& Hultman, E. (1973). Carbohydrate metabolism of the liver in normal man under varying dietary conditions. Scandinavian Journal of Clinical and Laboratory Investigation 32, 331-337.

Nosadini, R., Avogadro, A., Mollo, F., Marescotti, C., Tiengo, A., Duner, E., Merkel, C., Gatta, A., Zuin, R., DeKreutzenberg, S., Trevisan, T. \& Crepaldi, G. (1984). Carbohydrate and lipid metabolism in cirrhosis. Evidence that hepatic uptake of gluconeogenic precursors and of free fatty acids depends on effective hepatic blood flow. Journal of Clinical Endocrinology and Metabolism 58, 1125-1132.

Owen, O. E., Felig, P., Morgan, A. P., Wahren, J. \& Cahill, G. F. Jr (1969). Liver and kidney metabolism during prolonged starvation. Journal of Clinical Investigation 48, 574-583. 
Owen, O. E., Mozzoli, M. A., Reichle, F. A., Kreulen, T. H., Owen, R. S., Boden. G. \& Polansky, M. (1985). Hepatic and renal metabolism before and after portasystemic shunts in patients with cirrhosis. Journal of Clinical Investigation 76, 1209-1217.

Owen, O. E., Reichle, F. A., Mozzoli, M. A., Kreulen, T., Patel, M. S., Elfenbein, I. B., Golsorkhi, M., Chang, K. H. Y., Rao, N. S., Sue, H. S. \& Boden, G. (1981). Hepatic, gut, and renal substrate flux rates in patients with hepatic cirrhosis. Journal of Clinical Investigation 68, 240-252.

Owen, O. E., Trapp, V. Reichard, G. Jr, Mozzoli, M. A., Moctezuma, J., Paul, P., Scutches, G. L. \& Boden, G. (1983). Nature and quantity of fuels consumed in patients with alcoholic cirrhosis. Journal of Clinical Investigation 72, 1821-1832.

Rabkin, M. \& Blum, J. J. (1985). Quantitative analysis of intermediary metabolism in hepatocytes incubated in the presence and absence of glucagon with a substrate mixture containing glucose, ribose, fructose, alanine and acetate. Biochemical Journal 225, 761-786.

Radziuk. J. (1989). Hepatic glycogen in humans. I. Direct formation after oral or intravenous glucose or after a 24-h fast. American Journal of Physiology 257, E145-E157.

Reichard, G. A., Owen, O. E., Haff, A. C., Paul, B. \& Bortz, W. M. (1974). Ketone body production and oxidation in fasting obese humans. Journal of Clinical Investigation 53, 508-515

Remesy, C. \& Demigne, C. (1983). Changes in the availability of glucogenic and ketogenic substrates and liver metabolism in fed or starved rats. Annals of Nutrition and Metabolism 27, 57-70.

Rothman, D. L., Magnusson, I., Katz, L. D., Shulman, R. G. \& Shulman, G. I. (1991). Quantitation of hepatic glycogenolysis and gluconeogenesis in fasting humans with ${ }^{13} \mathrm{C}$ NMR. Science 254, 573-576.

Scholz, R., Schwabe, U. \& Soboll, S. (1984). Influence of fatty acids on energy metabolism. 1. Stimulation of oxygen consumption, ketogenesis, and $\mathrm{CO}_{2}$-production following addition of octanoate and oleate in perfused rat liver. European Journal of Biochemistry 141, 223-230.

Schwenke, W.-D., Soboll, S., Seitz, H. J. \& Sies, H. (1981). Mitochondrial and cytosolic ATP/ADP ratios in rat liver in vivo. Biochemical Journal 200, 405-408.

Seifter, S. \& Englard, S. (1988). Energy metabolism. In The Liver: Biology and Pathobiology. 2nd ed.. pp. 279-315 [J. M. Arias. W. B. Jacoby, H. Popper, D. Schachter and D. A. Shafritz, editors]. New York: Raven Press Ltd.

Thomas, C. D., Peters, J. C., Reed, G. W., Abumrad, N. N., Sun, M. \& Hill, J. O. (1992), Nutrient balance and energy expenditure during ad libitum feeding of high-fat and high-carbohydrate diets in humans. American Journal of Clinical Nutrition 55, 934-942.

Tygstrup, N., Winkler, K. \& Lundquist, F. (1965). The mechanism of the fructose effect on the ethanol metabolism of the human liver. Journal of Clinical Investigation 44, 817-830.

Vranic, M. (1992). Banting Lecture: Glucose turnover. A key to understanding the pathogenesis of diabetes (indirect effects of insulin). Diabetes $\mathbf{4 1}, 1188-1206$.

Wahren, J., Hagenfeldt, L. \& Felig, P. (1975). Splanchnic and leg exchange of glucose, amino acids and free fatty acids during exercise in diabetes mellitus. Journal of Clinical Investigation 55, 1303-1314.

Wasserman. D. H. \& Cherrington, A. D. (1991). Hepatic fuel metabolism during muscular work: role and regulation. American Journal of Physiology 260, E811-E824.

Yamatani, K., Quing Shi. Z., Giacca, A., Gupta, R., Fisher, S., Lickley. H. L. A. \& Vranic, M. (1992). Role of FFA-glucose cycle in glucoregulation during exercise in total absence of insulin. American Journal of Physiology 263, E646-E653. 